This item was submitted to Loughborough's Research Repository by the author.

Items in Figshare are protected by copyright, with all rights reserved, unless otherwise indicated.

\title{
In good times and in bad: bank capital ratios and lending rates
}

PLEASE CITE THE PUBLISHED VERSION

http://dx.doi.org/10.1016/j.irfa.2016.02.005

\section{PUBLISHER}

(c) Elsevier

VERSION

AM (Accepted Manuscript)

\section{PUBLISHER STATEMENT}

This work is made available according to the conditions of the Creative Commons Attribution-NonCommercialNoDerivatives 4.0 International (CC BY-NC-ND 4.0) licence. Full details of this licence are available at: https://creativecommons.org/licenses/by-nc-nd/4.0/

\section{LICENCE}

CC BY-NC-ND 4.0

\section{REPOSITORY RECORD}

Osborne, Matthew, Ana-Maria Fuertes, and Alistair Milne. 2016. "In Good Times and in Bad: Bank Capital Ratios and Lending Rates". Loughborough University. https://hdl.handle.net/2134/20545. 


\title{
In Good Times and in Bad: Bank Capital Ratios and Lending Rates
}

\author{
MATTHEW OSBORNE ${ }^{1,{ }^{*}}$, ANA-MARIA FUERTES ${ }^{2}$ and ALISTAIR MILNE ${ }^{3}$ \\ ${ }^{1}$ Bank of England, ${ }^{2}$ Cass Business School, City University London \\ ${ }^{3}$ Loughborough University, School of Business and Economics
}

\begin{abstract}
This paper investigates the relationship between bank capital ratios and lending rates using data from 1998 to 2012 for 13 large banks accounting for $75 \%$ of total UK lending. We document a substantial change in the coefficient of the Tier 1 capital ratio in reduced-form regressions for secured household lending rates; the coefficient changes from positive pre-crisis to negative in crisis. Significant changes are also detected in the relationship for unsecured household and corporate lending. Such instability is difficult to reconcile with many well-established theories of financial intermediation but is consistent with the relatively recent theories of bank portfolio decisions emphasising cyclical variation in bank leverage and risk-appetite.
\end{abstract}

Keywords: Bank capital; Interest margins; Bank regulation; Capital requirements.

JEL Classification: G01, G18, G28, G32, G38.

\footnotetext{
*Corresponding author: Ana-Maria Fuertes; Address: Cass Business School, 106 Bunhill Row, London EC1Y $8 T Z$. We thank the Bank of England for permission to use the data. Views expressed in this paper are those of the authors and do not necessarily reflect the official views of the Bank of England. We are grateful to two anonymous referees, Max Bruche, Manthos Delis, Claudia Girardone, Zulma González-Espinola, Ian Marsh, Peter Sinclair, Ron Smith, Sheida Teimouri, David VanHoose and John Wilson for valuable comments on earlier drafts, as well as participants at the 2015 INFINITI conference, the International Atlantic Economic Society Annual Conference; the Financial Engineering and Banking Society Annual Conference, ESCP Business School London; Quantitative and Qualitative Analysis in the Social Sciences Conference, Brunel University London; the IBEFA sessions at the Western Economic Association annual meeting; and seminar participants at Cass Business School and the Bank of England.
} 


\section{INTRODUCTION}

This paper examines the relationship between bank capital and loan interest rates for a panel of UK banks covering altogether about three quarters of the UK lending market. Our focus is on the cyclicality or state-dependence of this relationship during the period from October 1998 to December 2012, i.e. the possibility that it differs between episodes of rapid credit expansion (when times are 'good', before the global credit crisis) and periods of crisis and moderate credit growth (the 'bad' times, or subsequent years).

There are limits to the conclusions that can be drawn from an exercise of this nature. Bank capital decisions are endogenously determined alongside loan supply and interest rate decisions, and influenced also by loan demand. Our estimated coefficients cannot be reliably interpreted as representing the impact of an exogenous policy change such as an increase in the level of bank regulatory capital requirements. Nonetheless, even though the estimations we report are based on reduced-form models, they do provide some insights into a key question: what theory provides an adequate and consistent account of the portfolio and loan rate decisions of UK banks before and after the crisis?

The reason that even a reduced-form estimation strategy may be informative is that the most well-established theories prior to the crisis share one common feature: they adopt modelling frameworks in which bank portfolio choices are driven by bank specific factors such as capitalisation, liquidity and market power in deposit and lending markets. Cyclicality can appear in these models but only exogenously through changes in various explanatory model variables. Therefore these models predict that, once fully controlling for bank-specific and macroeconomic factors affecting loan supply and loan demand, then one should observe stable relationships between bank capital and the different 
dimensions of the bank portfolio decision such as the volume of bank loans and bank loan interest rates.

Our estimation results and tests clearly reject this prediction, suggesting instead that the association between bank capital ratios and lending rates alters substantially from the pre-crisis (or 'good times') period to the crisis (or 'bad times') period. For total bank lending, the coefficient on the Tier 1 capital ratio is significantly positive pre-crisis (October 1998-June 2007) and significantly negative in the period comprising the crisis (July 2007-December 2012). The corresponding coefficient in regressions for secured household lending (residential mortgages) is significantly positive prior to the crisis and significantly negative in the crisis period. For unsecured household lending we find instead a positive association in both the pre-crisis and crisis sub-periods, but a significant change in magnitude from relatively strong to weak. Finally, for corporate loans we find a significant negative association pre-crisis and no association in the crisis period.

These findings are robust to various specification tests that include: (i) formulating the panel model in 'error correction' form to capture the short-run dynamics of loan rates, (ii) estimating the panel model using rates on new business lending only, (iii) using data sampled at the quarterly rather than monthly frequency, (iv) explicitly controlling for bank- and time-varying regulatory capital requirements, and $(v)$ allowing not only for bank fixed effects but also time fixed effects so as to ensure that all (observed and unobserved) aggregate common factors influencing bank loan rate decisions are controlled for.

As we have stated, many well-established theories of bank decision-making are not consistent with this finding of pronounced cyclical instability in the relationship between bank capital and lending rates. One example are those models in which bank capital is provides banks with the incentive to apply effort to loan screening and monitoring. This 
theory predicts that banks with higher capital will make greater monitoring effort, lending more and offering lower rates of interest, but provides no obvious explanation for cyclical changes in the relationship between bank capital and loan interest rates. The same is true of the extensive theoretical literature that focuses on bank risk-return decisions. This literature provides a variety of predictions about relationships between bank capital and many dimensions of bank decision-making including lending rates, but, again, it provides no easy explanation for cyclical variation in those relationships.

Our finding of cyclical instability in the relationship between bank capital and lending rates is though consistent with theoretical perspectives on bank decision-making that have emerged since the crisis, exploring endogenous variation in bank leverage and risk appetite. This recent literature offers various rationales for changes in bank's willingness to accept risk exposure, between periods of rapid credit expansion - when, for example, the bank and its investors are optimistic about returns or-perceive risks are relatively low - and periods of slow credit expansion or contraction - when they may hold opposite views, becoming pessimistic about returns or perceiving risks as being relatively high.

The paper is structured as follows. Section 2 reviews some of the relevant theoretical and empirical literature. Section 3 describes our data and methodology. Section 4 presents the estimation results and a battery of robustness tests. Section 5 concludes.

\section{PRIOR LITERATURE}

\subsection{Theoretical perspectives}

This section reviews theories about the relationship between bank capital and other bank decisions (including lending rates), starting with those theories that allow for a 
disciplinary role of capital or for the interaction of capital structure and risk-return decisions. $^{1}$

One branch of theory, epitomised by the work of Holmström and Tirole (1997), emphasises the role of capital as a disciplining device ensuring that banks have sufficient 'skin in the game' to put the necessary effort into loan monitoring. ${ }^{2}$ It predicts that higher bank capital is associated with higher lending volume and lower lending rates. Other models highlighting the disciplinary role of short-term wholesale funding (e.g., Diamond and Rajan, 2000) suggest the contrasting prediction that a substitution of short-term debt funding for bank capital will result in higher lending volume and lower lending rates.

A much larger body of theory incorporates risk and the role of bank capital structure in bank risk-return decisions. The seminal contribution of Merton (1977) shows how deposit insurance provides bank shareholders with a put-option on bank returns. Lower bank capital can increase the magnitude of this put option (as it moves 'into the money') and increase the bank's incentives for risk-taking. This analysis of bank 'moral hazard' can be extended to accommodate bank franchise value or charter value lost in the event of failure (Marcus, 1984; Keeley, 1990). Under-capitalised banks may then seek to reduce their risk-exposure so as to protect their charter value (if this incentive outweighs the put option offered by the bank safety net).

These models of bank portfolio risk are further developed in the bank capital, competition and risk-taking literature; e.g., in Hellman et al. (2000) greater competition in

\footnotetext{
${ }^{1}$ For brevity, we focus on theoretical perspectives that provide relatively fully worked out models of the relationship between bank capital and bank lending volumes and/or interest rates. These are just one part of the broader literature exploring the reasons for departure from the Modigliani-Miller propositions for banks; for comprehensive reviews, see Miller (1995), and Berger et al. (1995). Nor do we attempt any review of the theory on the 'bank lending channel' initiated by Bernanke and Blinder $(1988,1992)$, in which better capitalised banks are predicted to respond less to changes in central bank reserves because they can substitute alternative market funding for reserved deposits.

2 This approach incorporates bank capital into the extensive earlier literature on bank monitoring and screening, originating with Leland and Pyle (1977) and Diamond (1984).
} 
deposit markets can reduce charter value and lead to increased risk-taking. In Boyd and De Nicoló (2005), greater competition lowers the interest rates paid by bank borrowers in turn ameliorating agency costs in loan contracts and reducing bank portfolio risk.

These models of bank risk-return decisions make ambiguous predictions about the relation between risk exposure, the quantity of bank lending and loan interest rates. A bank could increase its risk exposure either by lowering loan interest rates and hence, increasing its lending volume along a standard loan demand; or through a portfolio reallocation towards higher-risk assets that offer higher rates of return. In both scenarios, the bank's overall risk exposure is increased but the promised return, that is, the interest rate, can be either lower (in the first scenario) or higher (in the second scenario).

The common denominator of all these theories is that bank lending and portfolio decisions are determined by a range of bank-specific and aggregate factors. Once these factors are controlled for, one should observe a stable relationship between capital and loan interest rates (and other dimensions of bank portfolio decisions such as bank lending).

This is not the prediction of more recent (since the global financial crisis) contributions to the literature that emphasise the cyclicality of both bank leverage and bank willingness to accept risk ('risk-appetite'). Prominent contributions are those provided by Geanakoplos (2010) (this is per se not an analysis of banking but his models of leverage can be applied to banks), Adrian and Shin (2011) and Borio and Zhu (2012).

Various rationales have been provided for why this cyclical variation might happen; for a review, see Gambacorta and Marquez-lbañez (2011). The 'leverage cycle' in Geanakoplos (2010) arises from the interaction of heterogeneity in beliefs and constraints on borrowing. In expansionary periods optimistic investors are willing to pay high prices 
for assets which can generate a positive feedback - rising prices increase the access of these borrowers to funding which further increases asset prices.

A second rationale hinges on asset price volatility, notably in Brunnermeier and Pedersen (2009) where value-at-risk constraints determine access to leverage. This predicts multiple equilibria with the possibility of periods of low volatility, high asset prices and (by implication) high levels of lending; or high volatility, low asset prices and low lending levels.

A third rationale is behavioural, with reference to potential investor and intermediary irrationality. Periods of low interest rates and rapid growth may lead investors and bankers to underestimate risks. In Borio and Zhu (2012), during periods of low perceived risk and credit expansion (such as the 'great moderation' that preceded the global financial crisis), banks see less need to hold much capital against risk; more aggressive banks may operate with lower capital and more portfolio risk. This cyclicality may be reinforced by increased credit demand, a key mechanism in the Minsky (1986) model of financial instability, or by rises in the market value of bank capital (Borio et al., 2001). Another explanation offered by Gambacorta and Marquez-Ibañez (2011) is that cyclical fluctuations in bank lending may be driven by incentive arrangements that focus excessively on short-term performance.

This literature on cyclical leverage and risk-appetite is new and relatively immature. It again offers a range of predictions. Some versions - for example, those emphasising the role of asset price volatility and value-at-risk constraints - suggest that the relationship between bank capital and loan interest rates while varying cyclically might be still be explained by aggregate market- or economy-wide factors. Other versions of these newer theories (for example, those emphasising variation across banks in their optimism about 
future asset returns or perceptions of risk) explicitly introduce time-varying heterogeneity in bank behaviour, in which case the cyclical relationship between bank capital and loan interest rates cannot be empirically modelled by the inclusion of aggregate factors.

\subsection{Empirical literature}

Given the wide range of theoretical predictions, it is important to let the data speak on the relationship between bank capital and lending decisions (and other bank portfolio decisions). Empirical studies yield a range of findings. ${ }^{3}$ Various papers assess the impact of bank capital in the US 'credit crunch' of the late 1980s and early 1990s (see Sharpe, 1995, for a review). Some findings suggest that declines in bank capital reduce loan supply (e.g., Bernanke and Lown, 1991; Hancock and Wilcox, 1993; Peek and Rosengren, 1995). Several recent studies have examined the relationship between bank capital and other dimensions of bank decision-making during and following the global financial crisis. Banks with relatively illiquid asset portfolios were forced to deleverage (Cornett et al., 2011). Better capitalised banks increased balance sheet assets relative to other banks (Berger and Bouwman, 2013). Closest to our own findings are those of Košak et al. (2015) who analysing a sample of annual bank data examine the impact of bank capital on loan growth both pre-crisis and during the crisis. Their findings indicate that higher levels of capital and retail deposits are both associated with higher loan growth rates, and that the impact of Tier 1 bank capital on loan growth is very much higher during the crisis period.

\footnotetext{
${ }^{3}$ Due to space constraints, we do not review in detail the empirical literature on the 'bank lending channel' and the role of bank capital in response to changes of monetary policy rates; e.g., Kashyap and Stein (2000), Angeloni et al. (2003), Ashcraft (2006) and Jiménez et al. (2012). But we can note some parallels to our own findings, despite the notable differences in modelling approach. Gambacorta and Marquez-lbañez (2010) report cyclical variation in the bank lending channel while Jiménez et al. (2014) and loannidou et al. (2015) report increased risk-taking in response to cuts in monetary policy rates (but do not assess cyclical variation).
} 
Some empirical studies, like ours, assess the relationship between bank capital and loan interest rates. Most take a 'static' approach in which this relationship is assumed to be constant over time (Saunders and Schumacher, 2000; Demirgüç-Kunt and Huizinga, 1999; Carbó-Valverde and Rodríguez-Fernández, 2007; Hubbard et al., 2002; Santos and Winton, 2010). But others report cyclical variation in the relationship between lending rates (or interest margins) and capital even before the global financial crisis. Analysing UK syndicated loan data, Steffen and Wahrenburg (2008) find that undercapitalised banks during the 1996-2005 period charge higher interest rates during four episodes identified as recessionary. Fischer et al. (2013) study US syndicated loans and find that loan margins and the lender's capital ratio are negatively linked from 1988 to 1992 when both regulatory changes and market pressure force bank capital ratios upwards, and positively linked during 1993-2007 when banks operated in more benign conditions.

\section{DATA DESCRIPTION AND METHODOLOGY}

\subsection{Institutional features of UK bank lending markets}

We briefly describe some institutional features of the UK bank lending market. First, unlike in the US, there is relatively little fixed interest rate lending. Most mortgage lending is variable rate, either linked to wholesale lending rates such as the Bank of England base rate (the monetary policy rate), LIBOR or even more commonly at variable rates set at the discretion of lenders. Fixed rate residential mortgage lending is relatively uncommon and typically rates are fixed for only three to five years.

Second, also in comparison to other countries, the amount of UK corporate lending is relatively small. UK corporate lending (excluding commercial property mortgages) is only 
around $15 \%$ of total sterling bank lending and total UK corporate lending including commercial property represents only around $30 \%$ of sterling total bank lending.

Third, the level of competition varies considerably from one lending market to another. For residential mortgages and credit cards (the most important form of unsecured household lending) there are many competing providers. For corporate lending, especially SME borrowers, there are relatively few lenders.

UK banks, like those in other countries, were affected by the 2007-2009 global financial crisis (GFC). This arose in part because of UK bank holdings of US dollar subprime and other structured credit securities. But the main culprit was the extensive reliance of UK banks on wholesale funding and on securitisation (the closure of these markets was, for example, the reason for the failure of Northern Rock in September 2007).

The behaviour of end-of-month CDS prices for each UK bank based on 1- and 5-year senior and subordinated debt contracts are indicative of the impact of the crisis. Figure 1 plots the resulting composite CDS price as a percentage of its average pre-crisis 2004-06 value for each bank. CDS prices rise sharply from July 2007, coinciding with public concerns about the valuation of structured products and a drying up of the market for structured securities and for short-term asset-backed commercial paper (Brunnermeier, 2009).

[Figure 1 around here] 


\subsection{Key Variables: Lending Rates and Capital Ratios}

We use confidential data submitted by banks to the Bank of England (BoE) and Financial Services Authority (FSA). ${ }^{4}$ During the sample period, banks authorised in the UK submitted detailed data to the FSA on a quarterly basis on their balance sheets and capital adequacy. Large commercial banks also submitted data that enables the calculation of effective interest rates (defined below) to the BoE on a monthly basis, largely for the purpose of monitoring the pass-through of monetary policy decisions into market interest rates.

Differences between the BoE and FSA forms limit the scope of our sample. Whereas the FSA database covers every bank authorised in the UK, the effective rates collected by the BoE pertain to a small number of large retail banks which are the most active in the UK lending market. Unlike the BoE database, the FSA database does not include branches of foreign banks or building societies (since primary responsibility for their prudential supervision lies with the home regulator). Our final sample is necessarily limited to 13 large and UK-authorised banks that report in both datasets. These 13 banks account for around $75 \%$ of the UK lending market over the 1998-2012 sample period under study.

The sample banks are observed over two contrasting periods; one of exuberant credit conditions and benign macroeconomic performance up to 2007, and another of financial market stress and economic recession thereafter until the end of the sample in 2012. The main two variables, lending interest rates and capital ratios, are described next.

Effective lending rate. Banks submit to the FSA and BoE the average loan balances and interest accrued each month, from which the annualised effective lending rate

\footnotetext{
${ }^{4}$ The prudential functions of the FSA moved into the Prudential Regulatory Authority (PRA) in 2013.
} 


$$
l_{i t}=\frac{\text { interest accrued during month }}{\text { average loan balances during month }} \cdot \frac{\text { no.of days in year }}{\text { no.of days in month }}
$$

is calculated monthly from 1998 to 2012 for all loans, corporate loans, household secured loans and household unsecured loans. From 2004 to 2012, we can also calculate the interest accrued on new loans agreed during the month which allows for a better measure of the immediate response to changing funding conditions (new business lending rates).

We opted for the effective rate after considering two alternative sources of lending rates employed in extant studies. One is quoted interest rates representing the interest rates advertised for new business, which were used by Fuertes and Heffernan (2009) and Fuertes et al. (2010). These data have two main disadvantages: they do not include rates for large corporations which are generally not advertised; and they are quoted rather than agreed rates, which means they do not reflect the lending rates actually offered to borrowers (e.g., riskier borrowers may have to pay higher interest rates). Others use agreed rates on syndicated loans, e.g. Hubbard et al. (2002) and Santos and Winton (2010) in the US market, and Steffen and Wahrenburg (2008) in the UK market. While these represent interest rates agreed by syndicates of banks, they only include loans to large corporations and hence, do not include lending to households or to smaller businesses.

Capital ratio. The measure of bank capital ratio chosen for our empirical analysis is

$$
k_{i t}=\frac{\text { Tier } 1 \text { capital }}{\text { Total assets }}
$$

instead of the ratio of Tier 1 capital to the regulatory measure of risk-weighted assets. The main reason for this choice is that the risk-weighted assets calculation has undergone major changes during the sample period, specifically in 2007 when Basel II allows banks to 
use their own internal models to determine credit risk weights, and in 2011 when the socalled "Basel 2.5" increased risk weights in the trading book and tightened eligibility criteria for regulatory capital. In addition, risk-weighted ratios have been much criticised post-crisis since banks were able to increase leverage substantially while maintaining healthy regulatory risk-weighted capital ratios (Turner, 2009). We also prefer Tier 1 capital (common equity, reserves and certain hybrid equity-like securities) to the Tier 1 plus Tier 2 capital. This is because Tier 2 capital (subordinated debt and some hybrid instruments) was revealed by the crisis not to be truly loss-absorbing on a going concern basis.

\subsection{Panel Regression Model and Control Variables}

Our main reduced-form model, aimed at estimating the long-run association between bank lending rates $\left(l_{i t}\right)$ and bank capital ratios $\left(k_{i t}\right)$, can be formalised as follows

$$
\begin{aligned}
l_{i t}= & A_{i}+K k_{i t}+R r_{i t}+P p_{i t}+C c_{i t}+W w_{i t}+S s_{i t}+M m_{i t}+D d_{i t} \\
& +B b_{t}+F f_{t}+G g_{t}+u_{i t} .
\end{aligned}
$$

This is a panel regression with bank fixed effects $\left(A_{i}\right)$ and various controls to mitigate endogeneity arising from factors that simultaneously influence the lending interest rate and capital ratios; $i=1,2, \ldots, N$ are banks and $t=1, \ldots, T_{i}$ are months (the panel is unbalanced with a maximum $T_{i}$ of 148 months per bank, and an average $T_{i}$ of 97 months). The fixed effects are aimed at capturing unobserved bank-specific heterogeneity such as the business model. The estimation method is pooled ordinary least squares (OLS).

The overall motivation for the control variables is to mitigate endogeneity (omitted variable) bias in the coefficient of interest $K$. The controls $\left(r_{i t}, p_{i t}, w_{i t}, c_{i t}, s_{i t}, m_{i t}, d_{i t}\right)^{\prime}$ are 
bank-specific variables. ${ }^{5}$ The first four are measures of bank portfolio risk that, according to the theories outlined in Section 2 above, can be expected to be correlated both with lending rates and capital ratios. These are the ratio of risk-weighted assets to total assets $\left(r_{i t}\right)$, ratio of provisions to total loans and other debt instruments $\left(p_{i t}\right)$, ratio of write-offs to total loans $\left(w_{i t}\right)$, and ratio of corporate loans to total loans $\left(c_{i t}\right) .^{6}$

For the same reason, we also include each bank's total assets ( $s_{i t}$, expressed in $f$ billions) and measures of each bank's competitive position, the share of loans $\left(m_{i t}\right)$ and the share of total deposits $\left(d_{i t}\right) .^{7}$ These are standard controls in empirical banking. ${ }^{8}$

The remaining control variables $\left(b_{t}, f_{t}, g_{t}\right)^{\prime}$ are macroeconomic indicators aimed at controlling for business-cycle endogeneity arising from common shocks that influence both the lending rate and the capital ratio. The most obvious candidate is the BoE base rate that is the target interest rate for UK monetary policy ( $b_{t}$, expressed as a monthly average). In practice, interest rates for interbank lending can diverge from the BoE base rate due to expectations of losses which increase in periods of stress, together with term structure risk or the premium associated with lending at longer maturities. This motivates as control variable the spread of 1-year LIBOR over the BoE base rate $\left(f_{t}\right.$, also as a monthly average). Our third macroeconomic control is the output gap $\left(g_{t}\right)$ defined as

\footnotetext{
${ }^{5}$ In an additional exercise we include the average CDS price on 5-year debt of banks in our models as a market measure of bank risk. The variable is significantly positively linked with lending rates. However, CDS prices reflect banks' capital ratios as well as the portfolio risk of the banks, so we do not report these results.

${ }^{6}$ The provisions data (Bank of England form $\mathrm{PL}$ ) used to construct $p_{i t}$ include debt investments as well as loans, as provisions data exclusively for loans are not available over our entire sample period. To derive appropriate scalars for these variables we have constructed series for the stock of loans and investments which broadly match the provisions data (using the Bank of England forms BT and BE).

${ }^{7}$ The denominator is the total lending and deposits for all UK banks, not just those in our sample, from the Bank of England http://www.bankofengland.co.uk/statistics/Pages/bankstats/.

${ }^{8}$ Bank size is known to be correlated with capital ratios, and for this reason is used in most empirical studies of bank capital, e.g. Francis and Osborne (2012) and Jokipii and Milne (2008) and especially important in the context of lending rates where large banks may have lower funding costs (see Berger and Turk-Ariss, 2015).
} 
the deviation of actual real GDP from "potential" or trend real GDP to control for loan demand. ${ }^{9}$

We begin by estimating the long-run panel model (3) using total lending rates $\left(l_{i t}\right)$ as the dependent variable. Then we re-estimate the model for household secured loans $\left(l_{i t}^{\text {hsec }}\right)$, household unsecured loans $\left(l_{i t}^{\text {hunsec }}\right)$ and lending rates on corporate loans $\left(l_{i t}^{\text {corp }}\right)$. Accordingly, we redefine the ratio of write-offs to loans in each of these sectoral models as $w_{i t}^{\text {hsec }}, w_{i t}^{\text {hunsec }}$ and $w_{i t}^{\text {corp }}$ respectively, to reflect the specific risks in each loan category. We also redefine the loan market share variables as $m_{i t}^{\text {hsec }}, m_{i t}^{\text {hunsec }}$ and $m_{i t}^{\text {corp }}$ to reflect the bank's competitive position in each of these loan sub-markets. The sampling frequency is monthly for all variables except capital ratios $\left(k_{i t}\right)$, output gap $\left(g_{t}\right)$ and write-offs $\left(w_{i t}\right)$ which are only available quarterly. We convert them to monthly by linear interpolation.

We estimate the model using the entire sample together with a crisis dummy interacted with all the variables (including the bank fixed effects) to accommodate changes from the 'good times' period to the 'bad times' period in all the model parameters. Such a model produces identical results to estimating separate models for the two sub-periods, but has the advantage that it enables standard tests for the significance of parameter changes. The crisis dummy takes value 0 from the beginning of the sample on October 1998 until June 2007 (the 'good times' period), and 1 from July 2007 until the sample end on December 2012 (the 'bad times' period). The choice of July 2007 as the cut-off point is grounded empirically on the evolution of the banks' CDS prices since these are likely to reflect investor sentiment about each bank (Figure 1). The reason for including all months up to December 2012 in the 'bad times' period is that,

\footnotetext{
${ }^{9}$ The source of the output gap data is the OECD Economic Outlook.
} 
although the acute liquidity crisis was essentially resolved by early 2009 , the banking sector continued to be distressed due to low capital levels and the risk of losses stemming from the European sovereign debt crisis. As shown in Figure 1, the CDS indices remain at a higher level through 2009-2012.

\subsection{Robustness Tests}

In order to assess the robustness of the results, we carry out various robustness checks. We begin by embedding the long-run model (3) in lagged form, rewritten as $l_{i, t-j}=$ $l_{i, t-j}^{*}+u_{t-j}$, into a dynamic error correction model (ECM) which can be formalised as

$$
\Delta l_{i t}=c_{i}+\sum_{h=1}^{H} \beta_{h}^{L} \Delta l_{i, t-h}+\sum_{h=0}^{H} \boldsymbol{\beta}_{\boldsymbol{h}}{ }^{\prime} \Delta \boldsymbol{Z}_{\boldsymbol{i}, \boldsymbol{t}-\boldsymbol{h}}+\delta\left(l_{i, t-j}-l_{i, t-j}^{*}\right)+e_{i t} .
$$

Model (4a) is more general in that it nests model (3) and additionally captures the shortrun dynamics of lending rates; the vector $\mathbf{Z}_{i t} \equiv\left(k_{i t}, r_{i t}, p_{i t}, w_{i t}, c_{i t}, s_{i t}, m_{i t}, d_{i t}, b_{t}, f_{t}, g_{t}\right)^{\prime}$ gathers all the control variables. An ECM is previously used, for instance, by Fuertes and Heffernan (2009) and Fuertes et al. (2010) to analyse the long-run relationship between UK retail bank interest rates and the BoE base rate while simultaneously capturing their short-run behaviour. In this formulation, the lending rate changes $\left(\Delta l_{i t}\right)$ in response to deviations of the current lending rate $l_{i t-j}$ from its long-run path $l_{i t-j}^{*}$ which is often referred as the cointegration path; the economic intuition behind the concept of cointegration is that $l_{i t}^{*}$ acts as an attractor for the interest rate $l_{i t}$ over the long run so that the deviation $\left(l_{i t-j}-l_{i t-j}^{*}\right)$ can be conceptualised as a zero-mean stationary process. Hence, the term $\delta\left(l_{i, t-j}-l_{i, t-j}^{*}\right)$ has the interpretation of an error correction or 
catch-up mechanism that pulls the loan rate towards its long run path $l_{i t}^{*}$ in the wake of exogenous shocks. ${ }^{10}$

Accordingly, the above ECM can be conveniently re-parameterised as follows

$$
\Delta l_{i t}=\pi_{i}+\sum_{h=1}^{H} \beta_{h}^{L} \Delta l_{i, t-h}+\sum_{h=0}^{H} \boldsymbol{\beta}_{\boldsymbol{h}}{ }^{\prime} \Delta \boldsymbol{Z}_{\boldsymbol{i}, \boldsymbol{t}-\boldsymbol{h}}+\delta^{L} l_{t-j}+\boldsymbol{\delta} \boldsymbol{Z}_{\boldsymbol{t}-\boldsymbol{j}}+e_{i t}
$$

where $\delta^{L}$ and $\boldsymbol{\delta} \equiv\left(\delta^{K}, \delta^{R}, \delta^{P}, \delta^{W}, \delta^{C}, \delta^{S}, \delta^{M}, \delta^{D}, \delta^{B}, \delta^{F}, \delta^{G}\right)^{\prime}$ are long-run parameters. Therefore, the long-run effect of the capital ratio on the lending rate can now be obtained as $K=-\delta^{K} / \delta^{L}$. Similarly, the long-run effects of the controls gathered in $\boldsymbol{Z}_{i t}$ are given by the corresponding coefficient in the vector $\delta$ multiplied by $-1 / \delta^{L}$. The crucial shortrun effect, according to the goal of this paper, is the coefficient that measures the association between the capital ratio and lending rate which is given by $\beta^{K}=\sum_{h=0}^{H} \beta_{h}^{K}$. Model (4b) also includes bank-specific fixed effects and is estimated by OLS.

The appropriate lag parameter $j$ in the long-run component of the model, that is, the "error correction" mechanism that drives the lending rate towards its long-run path, is identified using the Akaike Information Criterion (AIC). This lag length reflects rigidities in the lending rate (e.g., difficulties in renegotiating contractual terms) that may prevent changes in the key variables driving the long run path, $l_{i t}^{*}$, from immediately materializing as changes in the lending rate, $\Delta l_{i t}$. For this identification purpose, we begin by estimating a baseline ECM with no additional lags of the first-differenced variables $(H=0)$ but considering different values for the lag parameter $j$ (from 1 to 6 months) in $\delta^{L} l_{t-j}$ and in the different variables $\boldsymbol{Z}_{t-j}$ that drive the long-run path. We select the lag that minimises the AIC. This lag length identification process is conducted for each (overall

\footnotetext{
${ }^{10}$ We deployed the panel Augmented Dickey Fuller (ADF) test on each of the variables in (2) in the pre-crisis and crisis periods and in the majority of cases (including our key variables of interest, the lending interest rate and the capital ratio) the null hypothesis of a unit root cannot easily be rejected.
} 
and sectoral loans) model, since loans in each sector may have different maturity profiles or contractual features which influence the mechanism of "catch-up" towards the longrun path. Once the appropriate lag length $j$ is identified, we augment the equation with as many short-term lags $h=1,2, \ldots, H$ as required to absorb the residual autocorrelation.

The lagged dependent variable $\left(\Delta l_{i, t-h}\right)$ can induce a bias in dynamic panel regression although any lagged-dependent-variable bias is likely to be small in our ECM estimation given the large $T$ dimension (about 150 months) relative to the cross-section dimension ( $N=13$ banks) of our sample. The most common method of dealing with this bias is to adopt the General Method of Moments (GMM) estimation; however, this is precluded in our context because of the small $N$. Alternative, one can estimate the ECM using the Corrected Least Squares Dummy Variable estimator of Bun and Kiviet (2003) and Bruno (2005) which is appropriate for small $N$; hence, we take this route. The bias-corrected coefficients are very close to those obtained by standard pooled OLS and so we only report the latter below.

We then present a range of further robustness checks. The first of these robustness checks is re-estimation of the long-run panel model, Eq. (3), with quarterly data to address concerns that observing the capital ratios, write-offs and output gap quarterly and then interpolating them to monthly observations might have contaminated our earlier findings.

The second robustness check is the inclusion of the capital requirement set by the FSA (denoted $k r_{i t}$ ) as additional control variable in Eq. (3) to mitigate another potential source of endogeneity bias for the coefficient of interest $K$ in model (3). Capital requirements can influence a bank's capital ratios and at the same time correlate with a bank's lending strategy and hence, influence the pricing and/or risk of loans; e.g., a bank pursuing a risky 
expansionary business strategy may be subject to higher capital requirements by the regulator. ${ }^{11}$ Capital requirements also changed substantially over the sample period. ${ }^{12}$

The additional control variable $k r_{i t}$ included in Eq. (3) for these purposes is the regulatory capital requirement set by the FSA until April 2008 as the ratio of Tier 1 capital to risk-weighted assets multiplied by the ratio of risk-weighted assets to total assets. From April 2008 onwards, we replace this capital requirement variable with a flat $8 \%$ ratio of Tier 1 capital to risk-weighted assets multiplied by the bank's ratio of risk-weighted assets to total assets wherever this exceeds the bank- and time-specific FSA capital requirement.

A third robustness check as regards estimation of Eq. (3) includes monthly time fixedeffects instead of the macroeconomic control variables $\left(b_{t}, f_{t}, g_{t}\right)^{\prime}$. The purpose is to ensure that our earlier results are not biased due to omission of other aggregate effects.

A final robustness check is an estimation of the long-run model (3) for total and sectoral lending using monthly data on new business loans defined as new loans or renegotiated outstanding loans during the month. This re-estimation is rather limited on two accounts. The first limitation is that data are available only for the period 2004-2012. The second limitation is that the portfolio-risk control variables $\left(r_{i t}, p_{i t}, w_{i t}, c_{i t}\right)$ and the loan market share variable $\left(m_{i t}\right)$ refer to existing business lending not to new business lending.

\footnotetext{
${ }^{11}$ Francis and Osborne (2012) and Aiyar et al. (2014) provide evidence of these links for the UK market. See also the literature cited in Section 2.2 on the US 'credit crunch' in the late 1980s and early 1990s.

${ }^{12}$ The pre-crisis capital requirements were set at the level of the regulatory risk-weighted total capital ratio and varied across banks and over time according to FSA judgements (see Francis and Osborne, 2012). From 2008, Tier 1 capital ratios rose substantially as the FSA set higher benchmark expectations for firms in the context of the government support package for major banks, including a minimum Tier 1 capital ratio of $8 \%$.
} 


\section{EMPIRICAL RESULTS}

\subsection{Preliminary Data Analysis}

The dynamics of monthly bank lending rates $\left(l_{i t}\right)$, write-offs to total loans $\left(w_{i t}\right)$ and Tier 1 capital ratio $\left(k_{i t}\right)$ during the entire sample period -October 1998 to December 2012 - is illustrated in Figure 2. The graphs show means across all the $i=1, \ldots, N$ banks $(N=13)$.

[Figure 2 around here]

Panel A shows the average monthly lending rate for all loans, household secured loans, household unsecured loans and corporate loans alongside the BoE base rate. During the pre-crisis period, all rates tracked the BoE base rate fairly closely with a spread of between 50-150 basis points (bp) for household secured loans and corporate loans and 400-700 bp for household unsecured loans, reflecting a notably larger credit risk premium for the latter. In 2008 there is a profound shift as the BoE base rate fell to an historic low of $50 \mathrm{bp}$ and the spread between lending rates and BoE base rate widened considerably to $300 \mathrm{bp}$ for household secured and corporate loans and to $800 \mathrm{bp}$ for household unsecured loans. The wider spread is likely to reflect both heightened loan credit risk premia and increases in banks' cost of funding due to investors' concerns about bank creditworthiness, as demonstrated by the CDS dynamics shown in Figure 1 and the spread between the BoE base rate and the 1-year LIBOR rate shown in Figure 2 (Panel A).

Panel B of Figure 2 shows the average write-offs over total loans for household secured lending, household unsecured lending and corporate lending. Again there is a clear contrast between the pre-crisis period and the crisis period. Household unsecured loans have a write-offs ratio of $1-2 \%$ in the pre-crisis period which doubles to around 5$8 \%$ in the crisis period, after which it broadly returns to pre-crisis levels. Corporate loan write-offs are between $0.3 \%$ and $0.7 \%$ in the pre-crisis period but rise to between $2 \%$ and 
$4 \%$ in the crisis period. Household secured write-offs are $0.01-0.03 \%$ pre-crisis and increase to around $0.08-0.13 \%$ during crisis period, before declining to $0.04-0.05 \%$ thereafter.

Panel $\mathrm{C}$ of Figure 2 shows the average of bank Tier 1 capital ratios and their riskweighted version. Both fell between 2004 and 2007 and then rose notably thereafter. Finally, the new business loan rates are shown in Panel D of Figure 2. As one would expect, new business rates are more volatile than existing rates. Nonetheless, despite significant spreads opening up in particular months of both positive and negative sign, there is no visual evidence that these spreads persist for any length of time.

The sample distribution of each variable (data pooled across banks and months) is summarised in Table 1 over the entire 1998-2012 period, the 'good times' or pre-crisis period (up to June 2007) and the 'bad times' or crisis period (from July 2007 onwards).

[Table 1 around here]

The capital ratio, write-offs to total loans ratio and LIBOR spread are much lower precrisis than in crisis. The BoE base rate, lending rates and output gap are also much lower in crisis. The risk-weighted assets to total assets ratio is lower in the crisis period. Lending rates are highest for unsecured lending, and fall little in the crisis period. The household secured and corporate loan rates are generally lower, and fall more notably in the crisis period.

\subsection{Estimation results}

Table 2 reports the estimation results for the baseline model, Eq. (3), adding interaction variables (i.e., the crisis dummy variable interacted with all other variables) so as to allow for full parameter heterogeneity from 'good times' to 'bad times'. We focus our 
discussion primarily on the main parameter of interest, the coefficient $K$ on the Tier 1 capital ratio, and we report Wald tests for the change in this parameter only, for space constraints. $^{13}$

[Table 2 around here]

In the all-loans regression, the model parameter $K$ is significantly positive during the pre-crisis period and becomes significantly negative during the crisis period. Turning to the different sub-categories of lending, there is a similarly large change, economically and statistically, in the coefficient $K$ for both household secured (residential mortgage) and household unsecured lending. While for both household secured and unsecured loans the capital ratios versus lending rates association is significantly positive in the 'good times' it becomes much smaller (unsecured loans) or changes sign (secured loans) in the 'bad times'.

The results for corporate lending also reveal a significant change in $K$ from the 'good times' to the 'bad times'. This change is, however, in the opposite direction to that detected for the two categories of household lending. Pre-crisis, the capital ratios versus loan rates association is significantly negative whereas during the crisis period the corresponding coefficient becomes essentially zero suggesting no association. As revealed by the Wald test statistics in Table 2 , all of these changes in the coefficient $K$ are highly significant.

We briefly comment on the estimates of the coefficients pertaining to the control variables in Table 2 . The share of corporate loans $\left(c_{i t}\right)$ is consistently positive and larger during the crisis (with the exception of corporate lending where the coefficient falls during the crisis). Bank size and loan and deposit market share are negative and highly

\footnotetext{
${ }^{13}$ Similar unreported Wald tests for the significance of changes in each of the other model parameters revealed that the change from pre-crisis to crisis is not just confined to the Tier 1 capital ratio coefficient.
} 
significant in the total loan model. For individual loan sectors, these variables are also highly significant, though there is a mixture of positive and negative coefficients.

The coefficient of the BoE base rate $\left(b_{t}\right)$ is positive and significant throughout, unsurprisingly. The coefficient of the output gap $\left(g_{t}\right)$ is consistently negative, but lower in the crisis period than pre-crisis, and while always significant pre-crisis it becomes insignificant during the crisis period for both categories of household lending.

We interpret the significant changes reported in Table 2 for the coefficient $K$ on the capital ratio in our loan rate regressions as evidence of a cyclical change in risk appetite of the kind discussed in the newer literature on cyclical bank leverage and risk appetite. Note that this interpretation can explain our finding of a significant change in sign of the coefficient $K$ that is of the opposite direction for corporate lending and for household lending. This is a consequence of the theoretical ambiguity about the relationship between risk appetite and lending rates discussed above in Section 2. Risk may be reduced in the crisis either by raising loan rates along a loan demand function for one category of lending (this might be the case for the household secured lending) while at the same time changing the composition of lending from relatively high risk loans offering higher rates of interest to relatively low risk loans offering lower interest rates for another category of lending (this might be the case for the corporate lending).

Turning to the robustness tests, the estimation results for the ECM specification (4b) that captures long- and short-term mechanisms are shown in Table 3. To preserve space, we report the long-run parameters for all variables as in Table 2, but regarding the shortrun effects we focus on the parameter of interest $\left(\beta^{K}\right)$ concerning the capital ratio.

[Table 3 around here] 
The results on the long-run association between bank capital ratios and lending rates obtained from the ECM are broadly consistent with those from the long-run model (3). In particular, the Wald test statistics still reveal a significant change from pre-crisis to crisis for household secured and corporate loans. For household secured rates and corporate rates, the change observed in the short-run coefficient $\beta^{K}$ from pre-crisis to crisis is aligned with the direction of the change in the long-run coefficient $K$, which emphasises the evidence.

All the remaining robustness tests concerning the long-run model (3) are gathered in Table 4. We report only the coefficient of interest $K$ and the corresponding Wald test statistic for the significance of change from the pre-crisis to crisis periods. The unreported coefficients on the control variables (the same controls as those used in our baseline analysis summarised in Table 2) do not change much from one robustness check to another; the full set of estimation results are available from the authors upon request.

\section{[Table 4 around here]}

Panel I of Table 4 reproduces our baseline estimates of $K$ from Table 2 for comparison. Panel II reports the same coefficient estimates using quarterly data. Panel III reports the coefficient estimates when including capital requirements as an additional control. In both of these panels the reported coefficient estimates and the Wald test statistic for the null hypothesis of no-change in $K$ are almost unchanged from the baseline results in Panel I.

Panel IV reports the coefficient estimates $K$ and corresponding Wald tests when replacing the three macroeconomic controls with time fixed-effects. The coefficient estimates for all loans and household secured lending are little changed. For household unsecured lending $K$ now switches from significantly positive pre-crisis to significantly 
negative in crisis. For corporate lending $K$ now switches from significantly negative precrisis to significantly positive in crisis. The Wald test statistic now rejects the no-change null hypothesis in the coefficient $K$ for all three sub-categories of lending as well as allloans.

Finally Panel $\mathrm{V}$ reports the re-estimation of $K$ in the long-run model, Eq. (3), once again with the crisis dummy interacted with all variables but now using new business lending rates as the dependent variable. Here, not surprisingly since we are losing two thirds of our pre-crisis sample (the estimation period is 2004-2012, as noted in Section 3.4) there is a substantial change in the pre-crisis coefficient estimates for $K$. Reassuringly, the coefficient estimates for the crisis period are relatively little changed. The coefficient $K$ on the capital ratio is now negative in all cases, both pre-crisis and during the crisis-period. This final robustness test suggests the possibility of further instability in the capital ratio versus lending rate relationship of interest within the precrisis period. These estimation results should be interpreted with caution however since, as noted earlier, the available portfolio-risk control variables and loan market share all refer to existing business lending.

\section{CONCLUSIONS}

This paper reports estimates of the relationship between bank capital and bank lending rates over the period 1998-2012 using data on the 13 largest UK banks that account for around $75 \%$ of UK lending. For household secured loans we find a positive long-run relationship between capitalisation and loan interest rates in the pre-2007 period ('good times') and a negative relationship during the subsequent period ('bad times'). For unsecured household lending we find instead a positive association in both sub-periods 
but with a substantial and significant change in magnitude from pre-crisis to crisis (from relatively strong to weak, respectively). Finally, for corporate loans we find a negative association pre-crisis and no association during the sample period that includes the crisis.

This finding of pronounced cyclical instability in the relationship between bank capital and lending rates is difficult to reconcile with many well-established theories of bank decision-making. We have reviewed theories in which bank capital is needed to provide banks with the incentive to apply effort to screening and monitoring of loans and also models of the impact of bank capitalisation on bank choices about portfolio risk and return. These analyses offer a variety of predictions about the relationship between bank capital and lending rates, but they all suggest that this relationship should be stable over time once fully controlling for aggregate macroeconomic and bank-specific factors.

Our reported coefficient instability might reflects shifts in the distribution of loan demand and therefore be consistent with these well-established theories of banking. For example, the instability may be a consequence of a pre-crisis shift in the distribution of the demand for lending across banks according to their particular regional or sectoral customer exposure that was subsequently reversed. Despite controlling for aggregate determinants of bank loan demand by including macroeconomic variables in our regressions (and replacing these with time-specific effects in a robustness check), we cannot definitively rule out the possibility of such a compositional shift in demand.

Still a plausible interpretation of our finding of instability in the parameter measuring the association between bank capital ratios and lending rates is that it is a consequence of cyclical mechanisms highlighted in the newer theoretical perspectives on bank decision-making that have emerged since the crisis. This recent literature suggests a variety of reasons for why the bank willingness to accept risk exposure may vary between 
periods of rapid credit expansion and periods of slow credit expansion or even contraction.

The precise mechanisms involved merit exploration. For example, some banks may have been more optimistic than others about future returns during the pre-crisis period and, as a result, operated with comparatively low levels of capital and accepted relatively high portfolio risk. Then, with the onset of the crisis, these same banks may have found themselves over-extended and needed to reduce portfolio risk. Further research is required on a wider range of bank decisions, and for other countries and time periods, to establish which variants of these newer theories of cyclical changes of bank leverage and risk-appetite offer the best explanations of observed bank portfolio and loan decisions. Work is also warranted on the impact of minimum regulatory capital requirements and of the newly introduced regulatory capital buffers, for example, the 'capital conservation buffer' in Basel III, both in expansionary and contractionary phases of the credit cycle. ${ }^{14}$

\footnotetext{
${ }^{14}$ Also, in relation to the literature on the 'bank-lending channel' discussed in previous footnotes, more research is warranted on cyclical variation in the response of bank loan volumes and bank risk-taking to changes in monetary policy rates.
} 


\section{References}

Adrian, T., Shin, H.S. (2011) Financial Intermediaries and Monetary Economics in Handbook of Monetary Economics 3, 601-650, eds. B.M. Friedman and M. Wooldford. North-Holland.

Aiyar, S., Calomiris, C. and Wieladek, T. (2014) Does Macro-Prudential Regulation Leak? Evidence from a UK Policy Experiment. Journal of Money, Credit and Banking 46, 181214.

Angeloni, I., Kashyap, A. K., and Mojon, B. (Eds.). (2003) Monetary Policy Transmission in the Euro Area: A Study by the Eurosystem Monetary Transmission Network. Cambridge University Press.

Ashcraft, A.B. (2006) New Evidence on the Lending Channel. Journal of Money, Credit and Banking 751-775.

Berger, A. N., and Bouwman, C. H. S. (2013) How Does Capital Affect Bank Performance during Financial Crises? Journal of Financial Economics 109, 146-176.

Berger, A. N., Herring, R. and Szegö, G. (1995) The role of capital in financial institutions. Journal of Banking \& Finance 19, 393-430.

Berger, A. N. and Turk-Ariss, R. (2015) Do depositors discipline banks and did government action during the recent crisis reduce this discipline? An international perspective. Journal of Financial Services Research 48, 103-126

Bernanke, B.S., Blinder, A.S. (1988) Credit, Money, and Aggregate Demand. American Economic Review 78, 435-439.

Bernanke, B., and Blinder, A. (1992) The Federal Funds Rate and the Channels of Monetary Transmission. American Economic Review 82, 901-921.

Bernanke, B. S., and Lown, C. S. (1991) The credit crunch. Brookings Papers on Economic Activity 2, 205-247.

Borio, C., Furfine, C., and Lowe, P. (2001) Procyclicality of the financial system and financial stability: issues and policy options. BIS Papers 1, 1-57

Borio, C., and Zhu, H. (2012) Capital Regulation, Risk-Taking and Monetary Policy: A Missing Link in the Transmission Mechanism? Journal of Financial Stability 8, 236251.

Boyd, J.H., and De Nicoló, G. (2005) The Theory of Bank Risk Taking and Competition Revisited. Journal of Finance 60, 1329-1343.

Brunnermeier, M. (2009) Deciphering the liquidity and credit crunch 2007-2008, Journal of Economic Perspectives 23, 77-100.

Brunnermeier, M. K., and Pedersen, L. H. (2008) Market Liquidity and Funding Liquidity. Review of Financial Studies 22, 2201-2238.

Bruno, G. S. F. (2005) Approximating the bias of the LSDV estimator for dynamic unbalanced panel data models, Economics Letters 87, 361-366.

Bun, M. J. G. and Kiviet, J. F. (2003) On the diminishing returns of higher order terms in asymptotic expansions of bias, Economics Letters 79, 145-152.

Carbó-Valverde, S. and Rodríguez-Fernández, F. (2007) The determinants of bank margins in European banking, Journal of Banking and Finance 31, 2043-2063. 
Cornett, M., McNutt, J., Strahan, P. and Tehranian, H. (2011) Liquidity risk management and credit supply in the financial crisis. Journal of Financial Economics 101, 297-312.

Demirgüç-Kunt, A. and Huizinga, H. (1999) Determinants of commercial bank interest margins and profitability: Some international evidence, The World Bank Economic Review 13, 379-408.

Diamond, D. (1984) Financial intermediation and delegated monitoring, Review of Economic Studies 51, 393-414.

Diamond, D. W., and Rajan, R. G. (2000) A Theory of Bank Capital. Journal of Finance 55, 2431-2465.

Fischer, M., Mattes, J. and Steffen, S. (2012) Bank capital, competition and loan spreads, ESMT European School of Management and Technology Berlin Working Paper, available at SSRN: http://ssrn.com/abstract=1483717.

Francis, W. and Osborne, M. (2012) How regulatory capital requirements affect bank behavior in the UK and implications for international capital standards, Journal of Banking and Finance 36, 803-816.

Fuertes, A.-M. and Heffernan, S. (2009) Interest rate transmission in the UK: A comparative analysis across financial firms and products, International Journal of Finance and Economics 14, 45-63.

Fuertes, A.-M., Heffernan, S. and Kalotychou, E. (2010) How do UK banks react to changing central bank rates?, Journal of Financial Services Research 37, 99-130.

Gambacorta, L., and Marquez-Ibañez, D. (2011) The Bank Lending Channel: Lessons from the Crisis, Economic Policy 26, 135-182.

Geanakoplos, J. (2010) The Leverage Cycle in NBER Macroeconomics Annual 24, 1-65, Eds. D. Acemoglu, K. Rogoff and M. Woodford. University of Chicago Press.

Hancock, D., and Wilcox, J. A. (1993). Has There Been a Capital Crunch: In Banking? The Effects on Bank Lending of Real Estate Market Conditions and Bank Capital Shortfalls. Journal of Housing Economics 3, 31-50

Hellmann, T. F., Murdock, K. C. and Stiglitz, J. E. (2000) Liberalization, Moral Hazard in Banking, and Prudential Regulation: Are Capital Requirements Enough? American Economic Review 90, 147-165.

Holmström, B. and Tirole, J. (1997) Financial intermediation, loanable funds, and the real sector, Quarterly Journal of Economics 112, 663-691.

Hubbard, R.G., Kuttner, K. and Palia, D. (2002) Are there bank effects in borrowers' cost of funds? Journal of Business 75, 559-581.

Ioannidou, V., Ongena, S. and Peydró, J.-L. (2015) Monetary Policy, Risk-Taking, and Pricing: Evidence from a Quasi-Natural Experiment, Review of Finance 19, 95-144.

Jiménez G., Ongena, S., Peydró, J. L. and Saurina, J. (2014) Hazardous times for monetary policy: What do twenty-three million bank loans say about the effects of monetary policy on credit risk?, Econometrica 82, 463-505.

Jiménez, G., Ongena, S., Peydró, J.-L. and Saurina, J. (2012) Credit Supply and Monetary Policy: Identifying the Bank Balance-Sheet Channel with Loan Applications, American Economic Review 102, 2301-2326. 
Jokipii, T. and Milne, A. (2008) The Cyclical Behaviour of European Bank Capital Buffers, Journal of Banking and Finance 32, 1440-1451.

Kashyap, A., and Stein, J. (2000) What Do a Million Observations on Banks Say About the Transmission of Monetary Policy?, American Economic Review 90, 407-428.

Keeley, M. (1990) Deposit insurance, risk, and market power in banking. American Economic Review 80, 1183-1200.

Košak, M., S. Li, I. Lončarski, and Marinč, M. (2015) Quality of Bank Capital and Bank Lending Behavior During the Global Financial Crisis, International Review of Financial Analysis 37, 168-183.

Leland, H. and Pyle, H. (1977) Informational asymmetries, financial structure, and financial intermediation, Journal of Finance 32, 371-387.

Marcus, A. (1984) Deregulation and bank financial policy, Journal of Banking and Finance 8, 557-565.

Merton, R. (1977) An analytic derivation of the cost of deposit insurance and loan guarantees an application of modern option pricing theory, Journal of Banking and Finance 1, 3-11.

Miller, M. H. (1995) Do the M \& M propositions apply to banks?, Journal of Banking and Finance 19, 483-489

Minsky, H. P. (1986) Stabilizing an Unstable Economy. New Haven: Yale University Press.

Peek, J., and Rosengren, E. S. (1995) The Capital Crunch: Neither a Borrower Nor a Lender Be, Journal of Money, Credit and Banking 27, 625-638.

Santos, J. and Winton, A. (2010) Bank capital, borrower power, and loan rates, AFA 2010 Atlanta Meetings Paper, available at SSRN: http://ssrn.com/abstract $=1343897$.

Saunders, A. and Schumacher, L. (2000) The determinants of bank interest rate margins: An international study, Journal of International Money and Finance 19, 813-832.

Sharpe, S. A. (1995) Bank Capitalization, Regulation, and the Credit Crunch: A Critical Review of the Research Findings. Washington Federal Reserve Board Finance and Economics Discussion Series 95-20.

Steffen, S and Wahrenburg, M. (2008) Syndicated loans, lending relationships and the business cycle, Goethe University Frankfurt Working Paper, available at SSRN: http://ssrn.com/abstract=1101022.

Turner, A. (2009) The Turner Review: A regulatory response to the global banking crisis. The Financial Services Authority, 25 The North Colonnade, Canary Wharf, London 


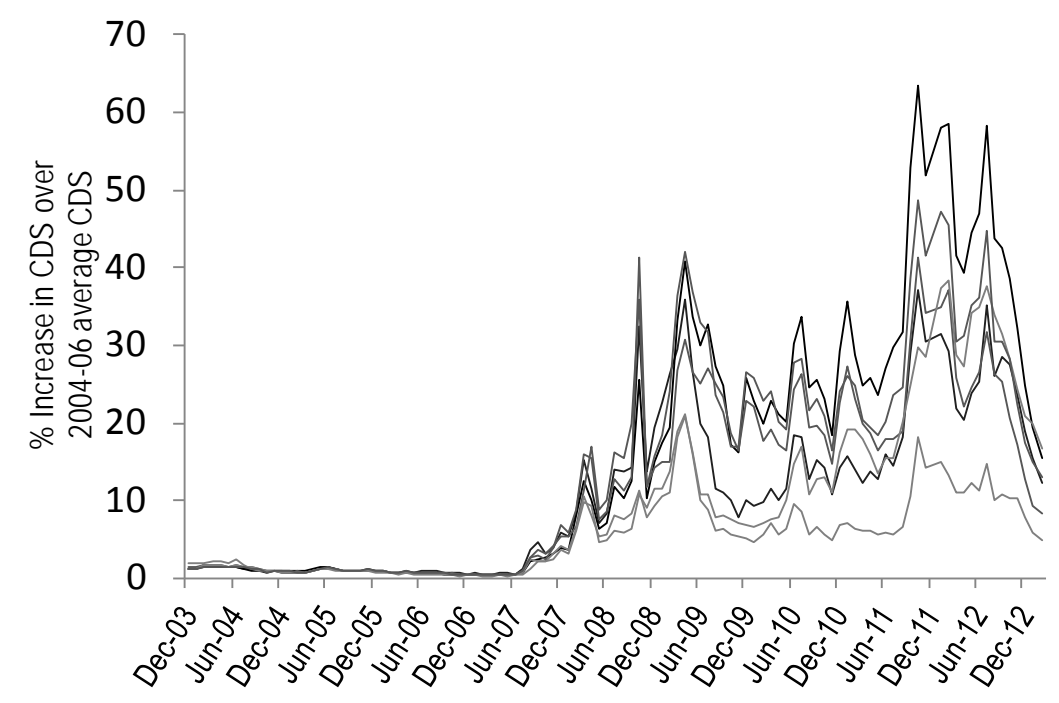

Figure 1. Bank CDS prices. Bank CDS prices are obtained by averaging the prices of 1 year senior, 1 year subordinated, 5 year senior and 5 year subordinated CDS contracts from Credit Market Analysis (CMA) and Thomson Reuters. The resulting bank CDS prices are expressed as ratios (in percentage) over the corresponding average of the bank CDS price from December 2003 to December 2006. The figure shows the ratios for 6 of the 13 sampled banks on which data is available over the entire sample period. 
Panel A: Lending Interest Rate

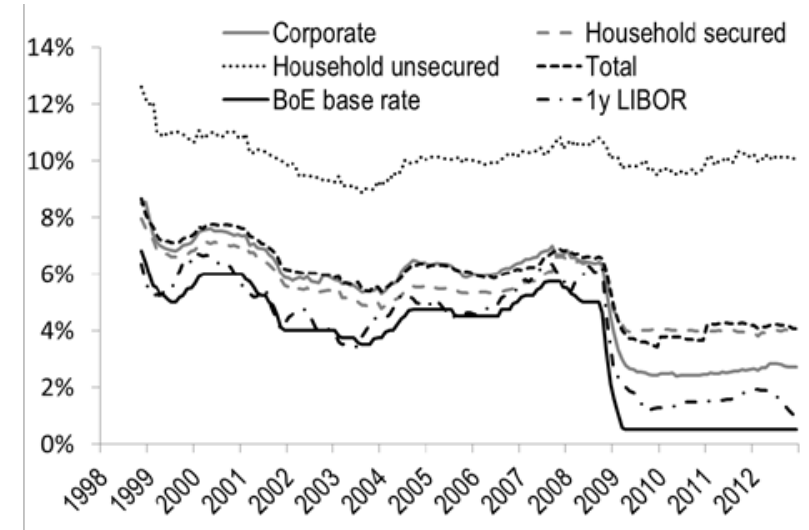

Panel C: Tier 1 Capital Ratio

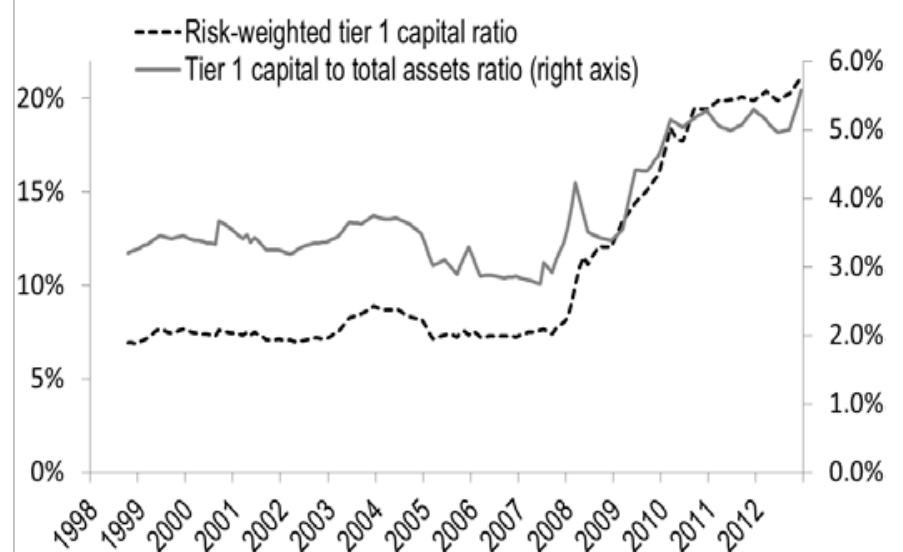

Panel B: Write-Off Ratio and Output Gap - Corporate - - Household secured

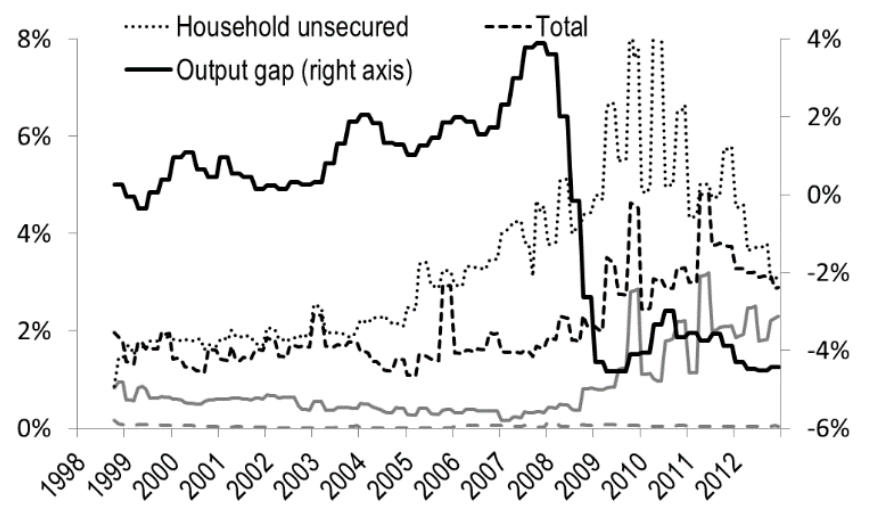

Panel D: New Business Lending Interest Rate

$$
\text { -All loans - Corporate loans }
$$$$
12 \% \quad \text { - - Household secured loans ....... Household unsecured loans }
$$

$10 \%$

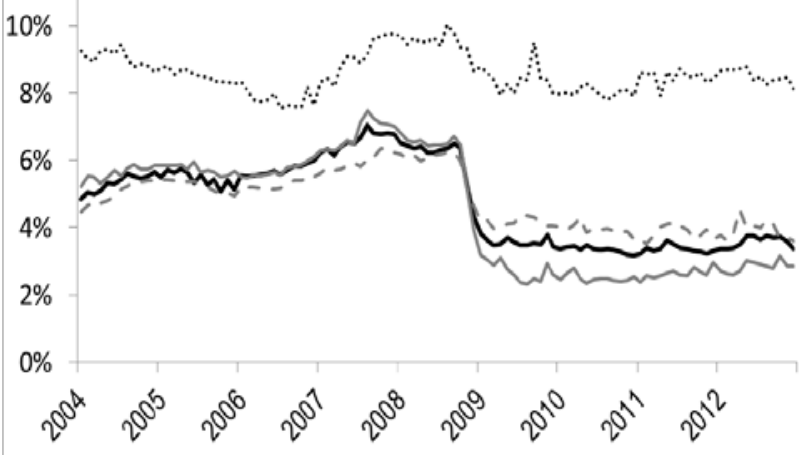

Figure 2. Lending rates, write-offs and Tier 1 capital. Panels A to $C$ plot average (across banks) loan interest rates, write-offs ratios alongside the output gap, and Tier 1 capital over the sample period October 1998 to December 2012. Panel D shows the average (across the 13 banks in the sample) interest rate on new loans granted each month from January 2004 to December 2012. These new loan rates are not strictly comparable to those graphed in Panel A as the new business rates cover slightly different categories of loans. See http://www.bankofengland.co.uk/statistics/Documents/reporters/defs/def er2014.pdf. 
Table 1. Descriptive statistics for lending rates, capital ratios and controls.

\begin{tabular}{|c|c|c|c|c|c|c|}
\hline & \multicolumn{2}{|c|}{ Full sample } & \multicolumn{2}{|c|}{ Pre-crisis period } & \multicolumn{2}{|c|}{ Crisis period } \\
\hline & Mean & StDev & Mean & StDev & Mean & StDev \\
\hline \multicolumn{7}{|l|}{ I. Bank-specific variables } \\
\hline Lending rate $\left(l_{i t}\right)$ & 6.02 & 1.51 & 6.51 & 1.24 & 4.73 & 1.40 \\
\hline Household secured lending rate $\left(l_{i t}^{h s e c}\right)$ & 5.46 & 1.38 & 5.91 & 0.83 & 4.63 & 1.76 \\
\hline Household unsecured lending rate $\left(l_{i t}^{\text {hunsec }}\right)$ & 10.14 & 1.89 & 10.15 & 2.15 & 10.09 & 1.07 \\
\hline Corporate lending rate $\left(l_{i t}^{\text {corp }}\right)$ & 5.69 & 1.87 & 6.43 & 1.17 & 3.72 & 1.94 \\
\hline Tier 1 capital ratio $\left(k_{i t}\right)$ & 3.61 & 1.55 & 3.29 & 1.29 & 4.46 & 1.84 \\
\hline Capital requirement $\left(k r_{j t}\right)$ & 2.03 & 0.80 & 1.99 & 0.80 & 2.14 & 0.81 \\
\hline Risk-weighted assets to total assets ratio $(r)$ & 40.80 & 17.30 & 44.63 & 17.63 & 30.68 & 11.32 \\
\hline Provisions to loans and investments ratio $\left(p_{i t}\right)$ & 0.77 & 0.58 & 0.83 & 0.58 & 0.59 & 0.53 \\
\hline Corporate loans to total loans ratio $\left(c_{i t}\right)$ & 20.44 & 15.56 & 20.09 & 1.67 & 21.35 & 13.30 \\
\hline Write-offs to loans ratio $\left(w_{i t}\right)$ & 1.95 & 1.86 & 1.61 & 16.33 & 2.87 & 2.02 \\
\hline Household secured write-offs to loans ratio $\left(w_{i t}^{h s e c}\right)$ & 0.04 & 0.06 & 0.03 & 0.05 & 0.05 & 0.08 \\
\hline Household unsecured write-offs to loans ratio ( $\left.w_{i t}^{\text {hunsec }}\right)$ & 3.10 & 2.92 & 2.29 & 2.18 & 5.00 & 3.49 \\
\hline Corporate write-offs to loans ratio $\left(w_{i t}^{\text {corp }}\right)$ & 0.74 & 1.31 & 0.48 & 0.69 & 1.41 & 2.09 \\
\hline Total assets, $€ b n\left(s_{i t}\right)$ & 258 & 258 & 156 & 151 & 526 & 289 \\
\hline Share of total loans $\left(m_{i t}\right)$ & 0.08 & 0.05 & 0.06 & 0.04 & 0.12 & 0.05 \\
\hline Share of household unsecured loans ( $m_{i t}^{\text {unsec }}$ ) & 0.06 & 0.04 & 0.05 & 0.04 & 0.09 & 0.04 \\
\hline Share of household secured loans ( $m_{i t}^{\mathrm{sec}}$ ) & 0.07 & 0.05 & 0.07 & 0.05 & 0.09 & 0.06 \\
\hline Share of corporate loans $\left(m_{i t}^{\text {corp }}\right)$ & 0.06 & 0.05 & 0.05 & 0.05 & 0.08 & 0.04 \\
\hline Share of deposits $\left(d_{i t}\right)$ & 0.06 & 0.04 & 0.05 & 0.04 & 0.08 & 0.03 \\
\hline \multicolumn{7}{|l|}{ II. Macroeconomic variables } \\
\hline BoE base rate $\left(b_{t}\right)$ & 3.99 & 1.86 & 4.81 & 0.80 & 1.84 & 2.11 \\
\hline 1y LIBOR spread to BoE base rate $\left(f_{t}\right)$ & 0.50 & 0.48 & 0.33 & 0.40 & 0.97 & 0.35 \\
\hline Output gap $\left(g_{t}\right)$ & 0.10 & 2.26 & 1.02 & 0.78 & -2.31 & 2.98 \\
\hline
\end{tabular}

Notes: The table reports the mean and standard deviation of all variables pooled across banks and months in pre-crisis (October 1998-June 2007) and crisis (July 2007-December 2012) periods. $l_{i t}$ is the lending rate as defined in (1) measured for all loans and, separately, for household (un)secured loans and corporate loans. $k_{i t}$ is the ratio of Tier 1 capital to total (unweighted) assets. $k r_{i t}$ is the capital requirement set by the FSA regulator as explained in Section 2.4 of the main text. $r_{i t}$ is the ratio of riskweighted to total assets. $p_{i t}$ is the ratio of provisions to total loans and debt investments. $c_{i t}$ is the ratio of corporate loans to total loans. $w_{i t}$ is the ratio of write-offs to total loans measured separately for household (un)secured and corporate loans. $s_{i t}$ is the total assets of each bank expressed in $f$ billions. $m_{i t}$ is each bank's share of loans which is measured separately for household (un)secured and corporate loans. $d_{i t}$ is each bank's share of total deposits. $b_{t}$ is the target overnight interest rate set by the BoE. $f_{t}$ is the spread of the 1 year LIBOR rate over the bank rate. $g_{t}$ is the OECD estimate of the UK output gap. 
Table 2. Estimation results for long-run model of lending rates.

\begin{tabular}{|c|c|c|c|c|c|c|c|c|}
\hline \multirow[b]{2}{*}{ Variable (coefficient) } & \multicolumn{2}{|c|}{ All loans } & \multicolumn{2}{|c|}{ Household secured } & \multicolumn{2}{|c|}{ Household unsecured } & \multicolumn{2}{|c|}{ Corporate } \\
\hline & Pre-crisis & Crisis & Pre-crisis & Crisis & Pre-crisis & Crisis & Pre-crisis & Crisis \\
\hline Tier 1 capital ratio $(K)$ & $\begin{array}{c}0.048^{\star \star *} \\
(0.016)\end{array}$ & $\begin{array}{c}-0.084^{\star \star *} \\
(0.014)\end{array}$ & $\begin{array}{c}0.077^{\star \star \star} \\
(0.013)\end{array}$ & $\begin{array}{c}-0.065^{\star \star \star} \\
(0.014)\end{array}$ & $\begin{array}{c}0.181^{* * *} \\
(0.042)\end{array}$ & $\begin{array}{l}0.051^{* *} \\
(0.021)\end{array}$ & $\begin{array}{c}-0.223^{\star \star \star} \\
(0.029)\end{array}$ & $\begin{array}{l}-0.016 \\
(0.016)\end{array}$ \\
\hline Wald test statistic (prob), Ho: $K^{\text {pre-crisis }}=K^{\text {crisis }}$ & \multicolumn{2}{|c|}{$37.28[0.000]$} & \multicolumn{2}{|c|}{$57.53[0.000]$} & \multicolumn{2}{|c|}{$6.52[0.011]$} & \multicolumn{2}{|c|}{$27.45[0.000]$} \\
\hline Risk-weighted assets to total assets ratio $(R)$ & $\begin{array}{l}-0.004^{\star *} \\
(0.002)\end{array}$ & $\begin{array}{c}-0.009 * * * \\
(0.003)\end{array}$ & $\begin{array}{c}-0.008^{\star \star \star} \\
(0.002)\end{array}$ & $\begin{array}{c}-0.009 * * * \\
(0.003)\end{array}$ & $\begin{array}{c}-0.031^{\star * *} \\
(0.005)\end{array}$ & $\begin{array}{c}-0.022^{\star * *} \\
(0.004)\end{array}$ & $\begin{array}{l}0.007^{\star *} \\
(0.003)\end{array}$ & $\begin{array}{c}-0.009 * * * \\
(0.003)\end{array}$ \\
\hline Provisions to loans and investments ratio $(P)$ & $\begin{array}{c}0.017 \\
(0.035)\end{array}$ & $\begin{array}{c}-0.021 \\
(0.069)\end{array}$ & $\begin{array}{c}-0.149 * \star \star \\
(0.040)\end{array}$ & $\begin{array}{c}0.043 \\
(0.068)\end{array}$ & $\begin{array}{c}0.021 \\
(0.099)\end{array}$ & $\begin{array}{c}-0.581^{\star * *} \\
(0.100)\end{array}$ & $\begin{array}{c}0.093 \\
(0.065)\end{array}$ & $\begin{array}{c}0.064 \\
(0.076)\end{array}$ \\
\hline Corporate loans to total loans ratio $(C)$ & $\begin{array}{c}0.003 \\
(0.002)\end{array}$ & $\begin{array}{c}0.044^{\star * *} \\
(0.003)\end{array}$ & $\begin{array}{l}0.006^{\star \star} \\
(0.003)\end{array}$ & $\begin{array}{c}0.016^{\star \star \star} \\
(0.002)\end{array}$ & $\begin{array}{c}0.003 \\
(0.007)\end{array}$ & $\begin{array}{c}0.013^{\star \star \star} \\
(0.003)\end{array}$ & $\begin{array}{c}0.029 * \star \star \\
(0.003)\end{array}$ & $\begin{array}{l}0.008^{\star *} \\
(0.003)\end{array}$ \\
\hline Write-offs to loans ratio $(W)$ & $\begin{array}{c}0.049^{* * *} \\
(0.009)\end{array}$ & $\begin{array}{c}0.007 \\
(0.010)\end{array}$ & $\begin{array}{l}0.012^{*} \\
(0.007)\end{array}$ & $\begin{array}{c}0.053^{\star \star \star} \\
(0.010)\end{array}$ & $\begin{array}{l}-0.005 \\
(0.024)\end{array}$ & $\begin{array}{c}-0.058^{\star * *} \\
(0.016)\end{array}$ & $\begin{array}{c}-0.041^{\star *} \\
(0.016)\end{array}$ & $\begin{array}{c}0.004 \\
(0.017)\end{array}$ \\
\hline Total assets $(S)$ & $\begin{array}{c}-0.000^{\star * *} \\
(0.000)\end{array}$ & $\begin{array}{l}-0.001^{* *} \\
(0.000)\end{array}$ & $\begin{array}{c}-0.001^{\star \star \star} \\
(0.000)\end{array}$ & $\begin{array}{c}0.001^{\star \star \star} \\
(0.000)\end{array}$ & $\begin{array}{c}-0.001^{* * *} \\
(0.000)\end{array}$ & $\begin{array}{c}0.002^{\star \star \star} \\
(0.000)\end{array}$ & $\begin{array}{l}-0.001^{\star *} \\
(0.000)\end{array}$ & $\begin{array}{l}-0.000 \\
(0.000)\end{array}$ \\
\hline Share of total deposits $(D)$ & $\begin{array}{l}-1.521^{*} \\
(0.780)\end{array}$ & $\begin{array}{c}-4.850^{* * *} \\
(0.742)\end{array}$ & $\begin{array}{c}-4.090^{\star \star \star} \\
(0.507)\end{array}$ & $\begin{array}{c}3.497^{\star * *} \\
(0.694)\end{array}$ & $\begin{array}{c}9.704^{\star * *} \\
(1.615)\end{array}$ & $\begin{array}{l}-1.044 \\
(0.833)\end{array}$ & $\begin{array}{c}11.820^{* * *} \\
(1.258)\end{array}$ & $\begin{array}{c}0.164 \\
(0.637)\end{array}$ \\
\hline Share of total loans $(M)$ & $\begin{array}{c}-2.514^{\star * *} \\
(0.804)\end{array}$ & $\begin{array}{c}-3.030^{* * *} \\
(1.096)\end{array}$ & & & & & & \\
\hline Household secured & & & & & & & & \\
\hline write-offs to loans ratio ( $W^{\text {hsec }}$ ) & & & $\begin{array}{c}-0.616^{\star \star \star} \\
(0.173)\end{array}$ & $\begin{array}{c}0.569 \star \star \star \\
(0.199)\end{array}$ & & & & \\
\hline share of loans $\left(M^{\text {hsec }}\right)$ & & & $\begin{array}{c}-2.469^{\star \star *} \\
(0.681)\end{array}$ & $\begin{array}{l}1.350^{*} \\
(0.794)\end{array}$ & & & & \\
\hline write-offs to loans ratio ( $W^{\text {hunsec }}$ ) & & & & & $\begin{array}{l}0.053^{\star *} \\
(0.024)\end{array}$ & $\begin{array}{c}0.007 \\
(0.008)\end{array}$ & & \\
\hline share of loans $\left(M^{\text {hunsec }}\right)$ & & & & & $\begin{array}{l}5.418^{\star} \\
(2.841)\end{array}$ & $\begin{array}{c}-4.524^{\star \star \star} \\
(1.709)\end{array}$ & & \\
\hline Corporate & & & & & & & & \\
\hline write-offs to loans ratio ( $\left.W^{\text {corp }}\right)$ & & & & & & & $\begin{array}{c}0.234^{* * *} \\
(0.035)\end{array}$ & $\begin{array}{l}-0.016 \\
(0.016)\end{array}$ \\
\hline share of loans $\left(M^{\text {corp }}\right)$ & & & & & & & $\begin{array}{c}-18.703^{\star \star \star} \\
(1.347)\end{array}$ & $\begin{array}{c}4.159^{\star \star \star} \\
(1.604)\end{array}$ \\
\hline BoE base rate $(B)$ & $\begin{array}{c}0.864^{\star * \star} \\
(0.011)\end{array}$ & $\begin{array}{c}0.637^{\star * *} \\
(0.025)\end{array}$ & $\begin{array}{c}0.849 * * * \\
(0.010)\end{array}$ & $\begin{array}{c}0.584^{\star \star \star} \\
(0.024)\end{array}$ & $\begin{array}{c}0.859^{\star * *} \\
(0.030)\end{array}$ & $\begin{array}{c}0.242^{\star \star \star} \\
(0.035)\end{array}$ & $\begin{array}{c}0.816^{\star * \star} \\
(0.021)\end{array}$ & $\begin{array}{c}0.961^{\star * *} \\
(0.027)\end{array}$ \\
\hline 1y LIBOR spread to BoE base rate $(F)$ & $\begin{array}{c}0.032 \\
(0.023)\end{array}$ & $\begin{array}{l}-0.030 \\
(0.053)\end{array}$ & $\begin{array}{c}0.051^{\star * *} \\
(0.020)\end{array}$ & $\begin{array}{l}-0.009 \\
(0.051)\end{array}$ & $\begin{array}{c}0.188^{\star * *} \\
(0.060)\end{array}$ & $\begin{array}{l}-0.094 \\
(0.075)\end{array}$ & $\begin{array}{c}0.013 \\
(0.042)\end{array}$ & $\begin{array}{c}0.019 \\
(0.059)\end{array}$ \\
\hline Output gap (G) & $\begin{array}{c}-0.246^{\star \star *} \\
(0.016)\end{array}$ & $\begin{array}{c}-0.050 * \star \star \\
(0.018)\end{array}$ & $\begin{array}{c}-0.266^{\star \star \star} \\
(0.015)\end{array}$ & $\begin{array}{l}-0.026 \\
(0.017)\end{array}$ & $\begin{array}{c}-0.574^{\star \star \star} \\
(0.045)\end{array}$ & $\begin{array}{l}-0.010 \\
(0.026)\end{array}$ & $\begin{array}{c}-0.107^{\star \star *} \\
(0.031)\end{array}$ & $\begin{array}{c}-0.077^{\star \star \star} \\
(0.020)\end{array}$ \\
\hline No. of observations $(T \times N)$ & 171 & & 13 & & 15 & & 17 & 07 \\
\hline No. of banks $(N)$ & 13 & & 1 & & 1 & & 1 & 2 \\
\hline Adjusted- $R^{2}$ & 0.9 & & 0.9 & & 0.8 & 77 & 0.9 & 29 \\
\hline
\end{tabular}

Notes: The table reports OLS estimates of the long-run equation (3) for lending rates with fixed bank effects. The data are monthly from October 1998 to June 2007 (pre-crisis period) and from July 2007 to December 2012 (crisis period) for $N$ banks. See note to Table 1 for variable definitions. The numbers in parentheses are Newey-West h.a.c. standard errors. The numbers in square brackets are $p$-values. 
Table 3. Estimation results for error correction model of lending rates.

\begin{tabular}{|c|c|c|c|c|c|c|c|c|}
\hline \multirow[b]{2}{*}{ Variable (coefficient) } & \multicolumn{2}{|c|}{ All loans } & \multicolumn{2}{|c|}{ Household secured } & \multicolumn{2}{|c|}{ Household unsecured } & \multicolumn{2}{|c|}{ Corporate } \\
\hline & Pre-crisis & Crisis & Pre-crisis & Crisis & Pre-crisis & Crisis & Pre-crisis & Crisis \\
\hline \multicolumn{9}{|l|}{ A. Long-run effects } \\
\hline Tier 1 capital ratio $(K)$ & $\begin{array}{l}0.068^{\star} \\
(0.040)\end{array}$ & $\begin{array}{l}-0.004 \\
(0.041)\end{array}$ & $\begin{array}{c}0.120 \\
(0.103)\end{array}$ & $\begin{array}{l}-0.180 \\
(0.121)\end{array}$ & $\begin{array}{l}0.283^{\star *} \\
(0.135)\end{array}$ & $\begin{array}{c}0.099 \\
(0.068)\end{array}$ & $\begin{array}{c}-0.265^{\star \star \star} \\
(0.086)\end{array}$ & $\begin{array}{c}0.132 \\
(0.107)\end{array}$ \\
\hline Wald test statistic (prob), Ho: $K^{\text {pre-crisis }}=K^{\text {crisis }}$ & \multicolumn{2}{|c|}{$1.59[0.207]$} & \multicolumn{2}{|c|}{$3.53[0.060]$} & \multicolumn{2}{|c|}{$1.48[0.224]$} & \multicolumn{2}{|c|}{$8.32[0.004]$} \\
\hline Risk-weighted assets to total assets ratio $(R)$ & $\begin{array}{c}-0.009^{\star *} \\
(0.004)\end{array}$ & $\begin{array}{c}-0.016^{\star \star} \\
(0.007)\end{array}$ & $\begin{array}{c}0.010 \\
(0.016)\end{array}$ & $\begin{array}{c}0.010 \\
(0.020)\end{array}$ & $\begin{array}{c}-0.040^{\star \star *} \\
(0.014)\end{array}$ & $\begin{array}{l}-0.020^{*} \\
(0.012)\end{array}$ & $\begin{array}{c}0.014 \\
(0.009)\end{array}$ & $\begin{array}{l}-0.038^{*} \\
(0.020)\end{array}$ \\
\hline Provisions to loans and investments ratio $(P)$ & $\begin{array}{c}0.097 \\
(0.088)\end{array}$ & $\begin{array}{c}0.211 \\
(0.188)\end{array}$ & $\begin{array}{l}-0.506 \\
(0.332)\end{array}$ & $\begin{array}{c}0.217 \\
(0.466)\end{array}$ & $\begin{array}{c}0.044 \\
(0.312)\end{array}$ & $\begin{array}{l}-0.276 \\
(0.312)\end{array}$ & $\begin{array}{c}0.058 \\
(0.190)\end{array}$ & $\begin{array}{c}0.438 \\
(0.465)\end{array}$ \\
\hline Corporate loans to total loans ratio $(C)$ & $\begin{array}{l}-0.001 \\
(0.005)\end{array}$ & $\begin{array}{c}0.047^{* \star *} \\
(0.008)\end{array}$ & $\begin{array}{l}-0.013 \\
(0.020)\end{array}$ & $\begin{array}{c}0.012 \\
(0.017)\end{array}$ & $\begin{array}{c}0.003 \\
(0.022)\end{array}$ & $\begin{array}{c}0.017 \\
(0.011)\end{array}$ & $\begin{array}{c}0.032^{\star * \star} \\
(0.009)\end{array}$ & $\begin{array}{l}-0.001 \\
(0.020)\end{array}$ \\
\hline Write-offs to loans ratio $(W)$ & $\begin{array}{c}0.070^{\star \star \star} \\
(0.023)\end{array}$ & $\begin{array}{c}0.137^{\star \star *} \\
(0.049)\end{array}$ & $\begin{array}{l}-0.014 \\
(0.052)\end{array}$ & $\begin{array}{l}-0.033 \\
(0.120)\end{array}$ & $\begin{array}{c}0.018 \\
(0.080)\end{array}$ & $\begin{array}{c}0.019 \\
(0.083)\end{array}$ & $\begin{array}{l}-0.032 \\
(0.050)\end{array}$ & $\begin{array}{l}-0.073 \\
(0.118)\end{array}$ \\
\hline Total assets (S) & $\begin{array}{l}-0.001^{*} \\
(0.000)\end{array}$ & $\begin{array}{c}-0.001^{* *} \\
(0.001)\end{array}$ & $\begin{array}{c}0.001 \\
(0.001)\end{array}$ & $\begin{array}{l}-0.000 \\
(0.001)\end{array}$ & $\begin{array}{l}-0.002^{*} \\
(0.001)\end{array}$ & $\begin{array}{l}0.002^{\star *} \\
(0.001)\end{array}$ & $\begin{array}{l}-0.000 \\
(0.001)\end{array}$ & $\begin{array}{l}-0.002 \\
(0.002)\end{array}$ \\
\hline Share of total deposits $(D)$ & $\begin{array}{l}-0.242 \\
(1.983)\end{array}$ & $\begin{array}{c}-4.692^{\star \star} \\
(1.970)\end{array}$ & $\begin{array}{l}-3.462 \\
(3.948)\end{array}$ & $\begin{array}{c}6.445 \\
(4.593)\end{array}$ & $\begin{array}{c}18.015^{\star \star \star} \\
(5.164)\end{array}$ & $\begin{array}{c}-0.772 \\
(2.600)\end{array}$ & $\begin{array}{c}11.911^{\star \star \star} \\
(3.726)\end{array}$ & $\begin{array}{c}0.097 \\
(3.833)\end{array}$ \\
\hline Share of total loans $(M)$ & $\begin{array}{l}-2.509 \\
(2.061)\end{array}$ & $\begin{array}{c}-5.895^{\star \star} \\
(2.968)\end{array}$ & & & & & & \\
\hline Household secured & & & & & & & & \\
\hline wite-offs to loans ratio $\left(W^{\text {hsec }}\right)$ & & & $\begin{array}{l}-1.500 \\
(1.368)\end{array}$ & $\begin{array}{c}-9.325 \\
(25.892)\end{array}$ & & & & \\
\hline share of loans $\left(M^{\text {hsec }}\right)$ & & & $\begin{array}{c}-11.460 * \\
(6.056)\end{array}$ & $\begin{array}{l}-2.401 \\
(5.109)\end{array}$ & & & & \\
\hline Household unsecured & & & & & & & & \\
\hline write-offs to loans ratio ( $W^{\text {hunsec }}$ ) & & & & & $\begin{array}{c}0.046 \\
(0.078)\end{array}$ & $\begin{array}{l}-0.058 \\
(0.104)\end{array}$ & & \\
\hline share of loans $\left(M^{\text {hunsec }}\right)$ & & & & & $\begin{array}{c}3.922 \\
(9.060)\end{array}$ & $\begin{array}{l}-7.124 \\
(5.270)\end{array}$ & & \\
\hline Corporate & & & & & & & & \\
\hline write-offs to loans ratio ( $W^{\text {corp }}$ ) & & & & & & & $\begin{array}{c}0.333^{\star \star \star} \\
(0.104)\end{array}$ & $\begin{array}{c}2.381 \\
(4.330)\end{array}$ \\
\hline share of loans $\left(M^{\text {corp }}\right)$ & & & & & & & $\begin{array}{c}-16.428^{\star \star \star} \\
(3.957)\end{array}$ & $\begin{array}{c}14.652 \\
(10.009)\end{array}$ \\
\hline BoE base rate $(B)$ & $\begin{array}{c}0.855^{\star \star \star} \\
(0.030)\end{array}$ & $\begin{array}{c}0.623^{\star \star *} \\
(0.080)\end{array}$ & $\begin{array}{c}0.691^{* * *} \\
(0.096)\end{array}$ & $\begin{array}{l}-0.252 \\
(0.350)\end{array}$ & $\begin{array}{c}0.904^{\star \star *} \\
(0.098)\end{array}$ & $\begin{array}{c}0.229^{*} \\
(0.130)\end{array}$ & $\begin{array}{c}0.839^{\star \star * *} \\
(0.065)\end{array}$ & $\begin{array}{c}0.929^{\star \star \star \star} \\
(0.197)\end{array}$ \\
\hline 1y LIBOR spread to BoE base rate $(F)$ & $\begin{array}{c}0.424^{\star \star \star} \\
(0.076)\end{array}$ & $\begin{array}{l}-0.127 \\
(0.157)\end{array}$ & $\begin{array}{c}0.859^{\star \star \star} \\
(0.264)\end{array}$ & $\begin{array}{l}1.284^{\star \star} \\
(0.584)\end{array}$ & $\begin{array}{l}0.542^{\star \star} \\
(0.243)\end{array}$ & $\begin{array}{c}0.115 \\
(0.261)\end{array}$ & $\begin{array}{c}0.214 \\
(0.155)\end{array}$ & $\begin{array}{c}0.125 \\
(0.394)\end{array}$ \\
\hline Output gap (G) & $\begin{array}{c}-0.190^{\star \star \star \star} \\
(0.042)\end{array}$ & $\begin{array}{l}-0.015 \\
(0.058)\end{array}$ & $\begin{array}{c}-0.331^{\star *} \\
(0.131)\end{array}$ & $\begin{array}{l}0.504^{\star \star} \\
(0.231)\end{array}$ & $\begin{array}{c}-0.423^{\star \star \star} \\
(0.148)\end{array}$ & $\begin{array}{c}0.021 \\
(0.096)\end{array}$ & $\begin{array}{l}-0.024 \\
(0.093)\end{array}$ & $\begin{array}{c}0.037 \\
(0.147)\end{array}$ \\
\hline B. Short-run effect & & & & & & & & \\
\hline Tier 1 capital ratio $\left(\beta^{\mathrm{K}}\right)$ & $\begin{array}{c}0.014 \\
(0.039)\end{array}$ & $\begin{array}{c}0.010 \\
(0.037)\end{array}$ & $\begin{array}{l}0.066^{\star} \\
(0.036)\end{array}$ & $\begin{array}{l}-0.009 \\
(0.029)\end{array}$ & $\begin{array}{c}0.081 \\
(0.076)\end{array}$ & $\begin{array}{c}0.073 \\
(0.069)\end{array}$ & $\begin{array}{l}-0.078 \\
(0.061)\end{array}$ & $\begin{array}{c}0.049 \\
(0.057)\end{array}$ \\
\hline No. of observations $(T \times N)$ & 17 & 02 & & 269 & 15 & & $16 s$ & \\
\hline No. of banks $(N)$ & 1 & & & 10 & 12 & & 12 & \\
\hline Adjusted- $R^{2}$ & 0.3 & 374 & 0.3 & 315 & 0.1 & & 0.2 & \\
\hline
\end{tabular}

Notes: The table reports OLS estimates of the Error Correction Model for lending rates with fixed bankspecific effects, equation (4b), with enough short-term lags $(H)$ to absorb all residual autocorrelation. The data are monthly from October 1998 to June 2007 (pre-crisis period) and from July 2007 to December 2012 (crisis period) for $N$ banks. The long-run effect of the capital ratio $\left(k_{i t}\right)$ on the lending rate $\left(l_{i t}\right)$ is measured by the composite parameter $K=-\delta^{K} / \delta^{L}$ as shown in the table; likewise, for all the other variables. The short-run effect of the capital ratio on the lending rate is measured by the composite parameter $\beta^{K}=\sum_{h=0}^{H} \beta_{h}^{K}$. See note to Table 1 for variable definitions. The numbers in parentheses are Newey-West h.a.c. standard errors. The numbers in square brackets are $p$-values. 
Table 4. Robustness tests for long-run model of lending rates.

\begin{tabular}{|c|c|c|c|c|c|c|c|c|}
\hline \multirow[b]{2}{*}{ Variable (coefficient) } & \multicolumn{2}{|c|}{ All loans } & \multicolumn{2}{|c|}{ Household secured } & \multicolumn{2}{|c|}{ Household unsecured } & \multicolumn{2}{|c|}{ Corporate } \\
\hline & Pre-crisis & Crisis & Pre-crisis & Crisis & Pre-crisis & Crisis & Pre-crisis & Crisis \\
\hline \multicolumn{9}{|l|}{ I. Baseline estimates (from Table 2) } \\
\hline \multirow[t]{2}{*}{ Tier 1 capital ratio $(K)$} & $0.048^{\star \star \star}$ & $-0.084^{\star \star *}$ & $0.077^{\star \star \star}$ & $-0.065^{\star \star \star}$ & $0.181^{\star \star \star}$ & $0.051^{\star *}$ & $-0.223^{\star \star *}$ & -0.016 \\
\hline & $(0.016)$ & $(0.014)$ & $(0.013)$ & $(0.014)$ & $(0.042)$ & $(0.021)$ & $(0.029)$ & $(0.016)$ \\
\hline Wald test statistic (prob), Ho: $K^{\text {pre-crisis }}=K^{\text {crisis }}$ & \multicolumn{2}{|c|}{$37.28[0.000]$} & \multicolumn{2}{|c|}{$57.53[0.000]$} & \multicolumn{2}{|c|}{$6.52[0.011]$} & \multicolumn{2}{|c|}{$27.45[0.000]$} \\
\hline \multicolumn{9}{|l|}{ II. Quarterly observations } \\
\hline \multirow[t]{2}{*}{ Tier 1 capital ratio $(K)$} & $0.048^{\star}$ & $-0.065^{\star \star}$ & $0.070^{\star \star \star}$ & $-0.075^{\star \star \star}$ & $0.170^{\star *}$ & $0.068^{*}$ & $-0.196^{\star \star \star}$ & -0.012 \\
\hline & $(0.026)$ & $(0.025)$ & $(0.020)$ & $(0.023)$ & $(0.070)$ & $(0.036)$ & $(0.053)$ & $(0.028)$ \\
\hline Wald test statistic (prob), Ho: $K^{\text {pre-crisis }}=K^{\text {crisis }}$ & \multicolumn{2}{|c|}{$10.73[0.001]$} & \multicolumn{2}{|c|}{$23.65[0.000]$} & \multicolumn{2}{|c|}{$1.24[0.265]$} & \multicolumn{2}{|c|}{$6.24[0.013]$} \\
\hline \multicolumn{9}{|l|}{ III. Controlling for capital requirements } \\
\hline \multirow[t]{2}{*}{ Tier 1 capital ratio $(K)$} & $0.054^{\star \star \star}$ & $-0.083^{\star \star \star}$ & $0.077^{\star \star \star}$ & $-0.065^{\star \star \star}$ & $0.174^{\star \star \star}$ & $0.051^{\star \star}$ & $-0.195^{\star \star \star}$ & -0.016 \\
\hline & $(0.016)$ & $(0.014)$ & $(0.013)$ & $(0.014)$ & $(0.040)$ & $(0.021)$ & $(0.028)$ & $(0.016)$ \\
\hline Wald test statistic (prob), Ho: $K^{\text {pre-crisis }}=K^{\text {crisis }}$ & \multicolumn{2}{|c|}{$41.04[0.000]$} & \multicolumn{2}{|c|}{$56.53[0.000]$} & \multicolumn{2}{|c|}{$6.53[0.012]$} & \multicolumn{2}{|c|}{$24.69[0.000]$} \\
\hline \multicolumn{9}{|l|}{ IV. Time fixed-effects } \\
\hline \multirow[t]{2}{*}{ Tier 1 capital ratio $(K)$} & $0.037^{\star *}$ & $-0.100^{* * *}$ & $0.083^{\star \star *}$ & $-0.099^{\star * *}$ & $0.199 * \star \star$ & $-0.176^{\star \star *}$ & $-0.278^{\star * *}$ & $0.315^{\star * *}$ \\
\hline & $(0.016)$ & $(0.025)$ & $(0.014)$ & $(0.020)$ & $(0.039)$ & $(0.059)$ & $(0.028)$ & $(0.043)$ \\
\hline Wald test statistic (prob), Ho: $K^{\text {pre-crisis }}=K^{\text {crisis }}$ & \multicolumn{2}{|c|}{$16.03[0.000]$} & \multicolumn{2}{|c|}{$23.73[0.000]$} & \multicolumn{2}{|c|}{$8.86[0.003]$} & \multicolumn{2}{|c|}{$53.69[0.000]$} \\
\hline \multicolumn{9}{|l|}{ V. New business lending rates } \\
\hline \multirow[t]{2}{*}{ Tier 1 capital ratio $(K)$} & -0.012 & $-0.050^{* *}$ & $-0.134^{\star * *}$ & $-0.065^{\star * *}$ & $-0.532^{\star * *}$ & -0.043 & -0.025 & -0.006 \\
\hline & $(0.063)$ & $(0.022)$ & $(0.042)$ & $(0.024)$ & $(0.103)$ & $(0.070)$ & $(0.037)$ & $(0.028)$ \\
\hline Wald test statistic (prob), Ho: $K^{\text {pre-crisis }}=K^{\text {crisis }}$ & \multicolumn{2}{|c|}{$0.38[0.539]$} & \multicolumn{2}{|c|}{$1.24[0.265]$} & \multicolumn{2}{|c|}{9.69 [0.002] } & $0.11[\mathrm{C}$ & .740] \\
\hline
\end{tabular}

Notes: The table reports OLS estimates of the coefficient of Tier 1 capital ratio in model (3) for lending rates. Panel I reproduces the estimates obtained in Table 2 for comparison. Panel II pertains to the estimation based on quarterly data. Panel III pertains to model (3) with capital requirements as additional control. Panel IV reports results for model (3) with time fixed effects instead of the macroeconomic variables. Panel V reports results for new business lending rates. In all cases, the data are monthly from October 1998 to June 2007 (pre-crisis) and from July 2007 to December 2012 (crisis) except for Panel V where the pre-crisis period is shorter from January 2004 to June 2007 due to data constraints on new business lending rates. See note to Table 1 for variable definitions. The numbers in parentheses are Newey-West h.a.c. standard errors. The numbers in square brackets are $p$-values. 